\title{
Evaluating salinity sources of groundwater and implications for sustainable reverse osmosis desalination in coastal North Carolina, USA
}

\author{
David S. Vinson • Haylee G. Schwartz • \\ Gary S. Dwyer • Avner Vengosh
}

\begin{abstract}
The natural and pumping-induced controls on groundwater salinization in the coastal aquifers of North Carolina, USA, and the implications for the performance of a reverse osmosis (RO) desalination plant have been investigated. Since installation of the well field in the Yorktown aquifer in Kill Devil Hills of Dare County during the late 1980s, the groundwater level has declined and salinity of groundwater has increased from $\sim 1,000$ to $\sim 2,500 \mathrm{mg} / \mathrm{L}$. Geochemical and boron isotope analyses suggest that the salinity increase is derived from an upflow of underlying saline groundwater and not from modern seawater intrusion. In the groundwater of four wells supplying the plant, elevated boron and arsenic concentrations were observed $(1.3-1.4 \mathrm{mg} / \mathrm{L}$ and $8-53 \mu \mathrm{g} / \mathrm{L}$, respectively). Major ions are effectively rejected by the RO membrane (96-99\% removal), while boron and arsenic are not removed as effectively (16-42\% and 54 $75 \%$, respectively). In coming decades, the expected rise of salinity will be associated with higher boron content in the groundwater and consequently also in the ROproduced water. In contrast, there is no expectation of an increase in the arsenic content of the salinized groundwater due to the lack of increase of arsenic with depth and salinity in Yorktown aquifer groundwater.
\end{abstract}

Keywords Coastal aquifers - Stable isotopes - Arsenic . Reverse osmosis desalination · USA

Received: 30 July 2010/Accepted: 1 April 2011

(C) Springer-Verlag 2011

D. S. Vinson • H. G. Schwartz · G. S. Dwyer • A. Vengosh ( Division of Earth and Ocean Sciences,

Nicholas School of the Environment,

Duke University,

P.O. Box 90328, Durham, NC 27708, USA

e-mail: vengosh@duke.edu

Tel.: +1 (919) 681-8050

Fax: +1 (919) 684-5833

H. G. Schwartz

School of Law,

\section{Introduction}

Population growth in coastal areas has created significant pressure on, and depletion of, water resources in coastal aquifers (e.g., Jones et al. 1999; Barlow 2003; Ranjan et al. 2006), and climate change models predict increasing depletion of coastal freshwater resources during the coming decades (Ranjan et al. 2006). Desalination of seawater and saline groundwater is one alternative that could provide tap water to sustain the increasing demands in coastal areas (Salgot and Tapias 2004). While seawater desalination involves large capital investments and advanced technological solutions (e.g., the Ashqelon desalination plant in Israel, Gorenflo et al. 2007), using saline groundwater from coastal aquifers is a cheaper solution than seawater desalination, given the lower salinity of the groundwater resource. Yet, the ability to pump saline groundwater without major fluctuations in salinity is important for sustainable utilization of this water source for desalination.

This study is focused on saline groundwater and desalination from the southeastern Atlantic coast region of the USA. Coastal areas are the fastest growing regions in the USA, and are expected to continue to expand in the future (Barlow 2003). As with many other coastal areas, the southeastern Atlantic coast region is experiencing a large increase in population, resulting in increasing pressure on local groundwater resources. In Dare County, North Carolina, which includes the barrier island areas that are the setting for this study (Fig. 1), population grew from 23,000 to 34,000 from 1991 to 2009 , a $48 \%$ increase (North Carolina, Office of State Budget and Management, State Demographics Branch 2010). In addition, Dare County has undergone a transition from high summer demand to year-round demand and a sharp increase in overall water demand (Dare County Water Department 2006). Similar to other inhabited coastal areas (Fig. 1), the approach in Dare County to meet increasing demand was the installation of several reverse osmosis (RO) desalination plants in which local saline groundwater is used as the water source (Oreskovich and Watson 2003; Dare County Water Department 2006). The hydrogeologic properties of the Atlantic coast (Meisler 1989; Barlow 


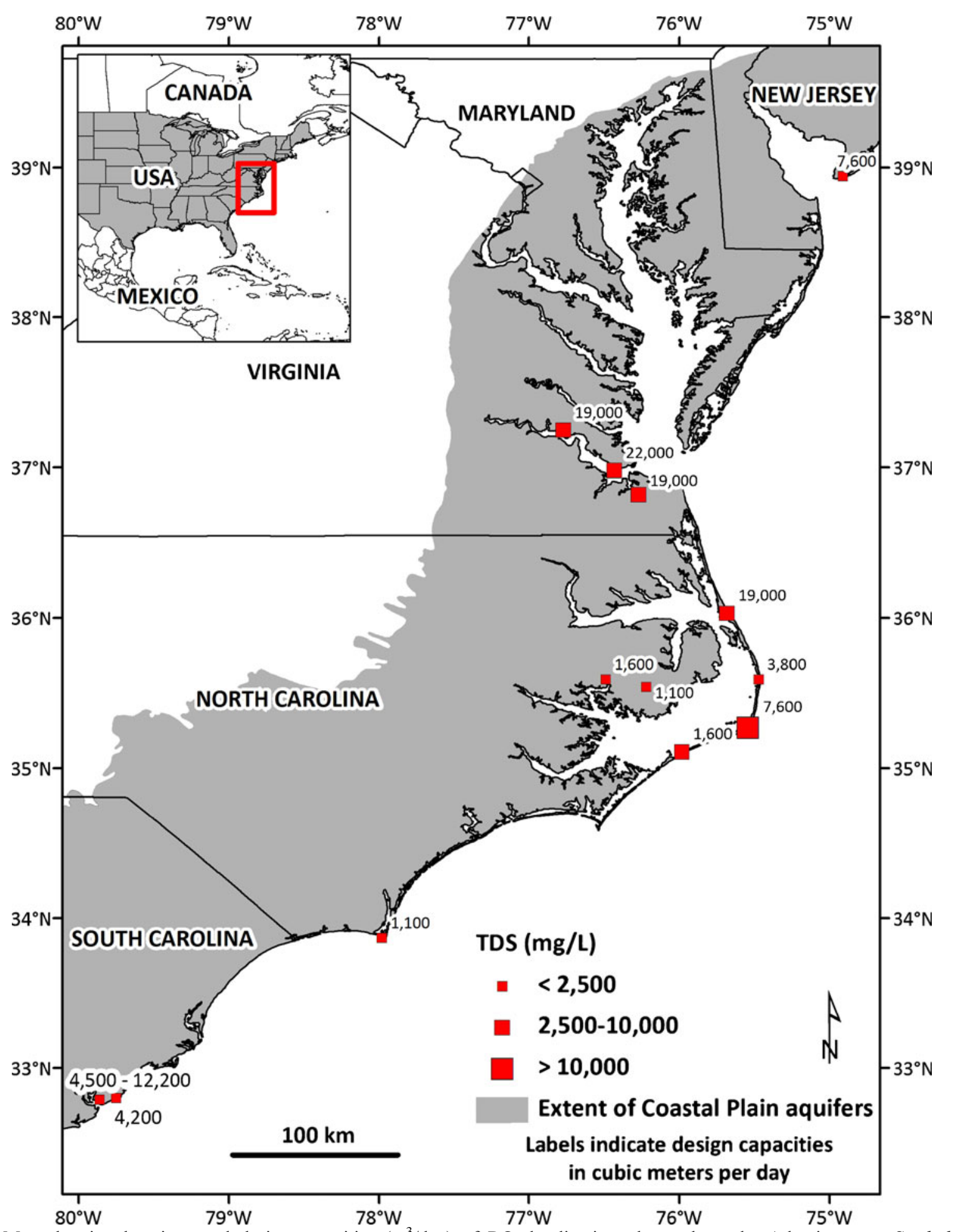

Fig. 1 Map showing locations and design capacities $\left(\mathrm{m}^{3} /\right.$ day) of RO desalination plants along the Atlantic coast. Symbol size is proportional to total dissolved solids $(T D S)$ of feed groundwater to the RO plants. Data from the American Membrane Technology Association (AMTA 2011)

2003) enable water systems such as Dare County's to pump saline groundwater for the RO desalination plant instead of the more costly option of seawater desalination to replace limited supplies of surface water and fresh, shallow groundwater (Fig. 1). Currently, the Dare County Water Department operates three small desali- nation plants with production rates of $230-7,570 \mathrm{~m}^{3} /$ day $\left(0.08-2.76 \times 10^{6} \mathrm{~m}^{3} /\right.$ year $)$. The Dare County North RO Water Plant at Kill Devil Hills is the focus of this study, and generates $3,780 \mathrm{~m}^{3} /$ day permeate (treated) water that is blended with raw well water to produce $4,055 \mathrm{~m}^{3} /$ day (about $1.5 \times 10^{6} \mathrm{~m}^{3} /$ year). 
Desalination of brackish and/or saline groundwater presents other challenges such as the presence of naturally occurring contaminants in groundwater that are not removed effectively by $\mathrm{RO}$ desalination, including boron (US Environmental Protection Agency (EPA) 2008; Kloppmann et al. 2008) and uncharged forms of arsenic (Oreskovich and Watson 2003; Pawlak et al. 2006; George et al. 2006; Moore et al. 2008; Walker et al. 2008; Geucke et al. 2009). High boron concentrations are commonly observed in coastal aquifers due to boron desorption from marine sediments (e.g., D'Avino and Spandre 1995; Vengosh and Spivack 1999) and at near-neutral $\mathrm{pH}$, boron occurs primarily as uncharged $\mathrm{B}(\mathrm{OH})_{3}{ }^{0}$, which is not efficiently adsorbed and can accumulate in groundwater. Although saline waters may contain high arsenic concentrations (Smedley and Kinniburgh 2002; Scanlon et al. 2009), high-As groundwater is commonly understood as a function of the solid-phase arsenic source and desorption processes that are sensitive to $\mathrm{pH}$, redox conditions, and/or surface charge modification by cations (Smedley and Kinniburgh 2002; Haque et al. 2008; Scanlon et al. 2009). At near-neutral pH, oxidized $\mathrm{As}(\mathrm{V})$ occurs as anionic $\mathrm{H}_{2} \mathrm{AsO}_{4}{ }^{-}$or $\mathrm{HAsO}_{4}{ }^{2-}$, subject to $\mathrm{pH}$-sensitive desorption from metal oxides; reduced As(III) exists primarily as uncharged $\mathrm{H}_{3} \mathrm{AsO}_{3}{ }^{0}$ that is less effectively adsorbed than anionic $\mathrm{As}(\mathrm{V})$. Redox processes subsequent to $\mathrm{Fe}$ and $\mathrm{Mn}$ oxide reduction such as sulfate reduction, may further affect As mobility in anoxic aquifers (e.g., Kirk et al. 2004).

In addition to the potential water-quality problems introduced by natural contaminants, the stability of the quality of the saline-water source for the RO plant is in question, particularly for aquifers that are constantly being exploited beyond natural replenishment. This paper aims to investigate these two issues. First, water-quality changes that have occurred since the installation of the pumping wells for the RO desalination plant in Dare County during the late 1980s are investigated. Major elements coupled with stable oxygen, hydrogen, and boron isotopes are used as indicators for tracing the origin of the saline groundwater. Second, the relationship between the chemical composition of the saline groundwater and the rejection performance, particularly of boron and arsenic, by RO desalination in the Dare County North Reverse Osmosis Water Plant is assessed. In addition, predictions are made on how the long-term changes in the water quality of the saline groundwater source will affect the quality of the produced water generated by the RO plant. The case study of Dare County in North Carolina is representative of numerous areas along the Atlantic coast that are facing similar challenges for sustainable water supply under increasing water demands (Fig. 1).

\section{Hydrogeologic setting}

The Atlantic Coastal Plain extends from Florida to New York and is comprised of thick clastic sediments and marine limestones from Jurassic to Quaternary in age. In North Carolina, the area of this research, the Coastal Plain may be divided into nine distinct sand and limestone aquifers (Fig. 2a-b). Across a gently dipping outcrop belt about $200 \mathrm{~km}$ wide, these sediments reach a thickness of approximately 3,000 $\mathrm{m}$ (Winner and Coble 1996). In the aquifers of the Atlantic Coastal Plain, waters moving down-gradient undergo ion exchange reactions that remove $\mathrm{Ca}$ and $\mathrm{Mg}$; thus, in the down-gradient, confined portions of the aquifers, Na-bicarbonate waters dominate (Chapelle and Knobel 1983; Knobel et al. 1998) before mixing with saline $\mathrm{Na}-\mathrm{Cl}$ waters. Overall, physical and geochemical characteristics suggest that this saline source in the deep confined Coastal Plain aquifers is dilute fossil seawater and/or brine and that the salinity level of this water is derived from mixing caused by Quaternary sea level fluctuations (Manheim and Horn 1968; Meisler 1989; Barlow 2003). No confining unit separates the aquifer from the natural salinity source down-dip, whereas regional confining unit(s) separate the aquifer system from modern seawater. Therefore, intrusion of modern seawater is not suspected as a significant cause of the groundwater's salinity. Although the authors know of no isotopic measurements of the confined coastal aquifers of eastern North Carolina (e.g., ${ }^{14} \mathrm{C}$ ) that would directly address the antiquity of this salinewater source, ${ }^{14} \mathrm{C}$ dating of inland waters in confined Cretaceous Coastal Plain aquifers at similar depths as this study indicates long groundwater residence time since recharge (3,200-26,000 years; Kennedy and Genereux 2007). Therefore, surface-derived inputs to these confined aquifers are not substantial. Redox conditions in the confined Coastal Plain aquifers are generally anoxic and sulfate-reducing (Chapelle and McMahon 1991; Knobel et al. 1998; Kennedy and Genereux 2007).

The Yorktown aquifer, in which the study wells are located, is an upper Miocene to Pliocene marine sand containing abundant silt, clay, and carbonate shell material and is the uppermost confined aquifer in the Atlantic Coastal Plain (Fig. 2d; Winner and Coble 1996). The western, relatively shallow section of the Yorktown aquifer receives sufficient recharge from the surface that only localized water level declines have been observed (dePaul et al. 2008). However, the eastern one third of the Yorktown aquifer in North Carolina, including the study area, exhibits higher hydraulic head than overlying aquifers as is generally true in the confined Coastal Plain aquifers (Winner and Coble 1996). Like other Coastal Plain aquifers, the Yorktown aquifer becomes thicker and more saline down-dip towards the Atlantic Ocean; the point at which $\mathrm{Cl}<250 \mathrm{mg} / \mathrm{L}$ at the base of the Yorktown aquifer lies approximately $60 \mathrm{~km}$ inland of the study area (Lautier 2009). In the vicinity of the study site, the Yorktown aquifer extends from a depth of $\sim 50 \mathrm{~m}$ to at least $200 \mathrm{~m}$ below sea level and is overlain by a silt- and clay-rich confining unit up to $15 \mathrm{~m}$ thick and by the Quaternary surficial aquifer (Fig. 2c-d; Winner and Coble 1996). 

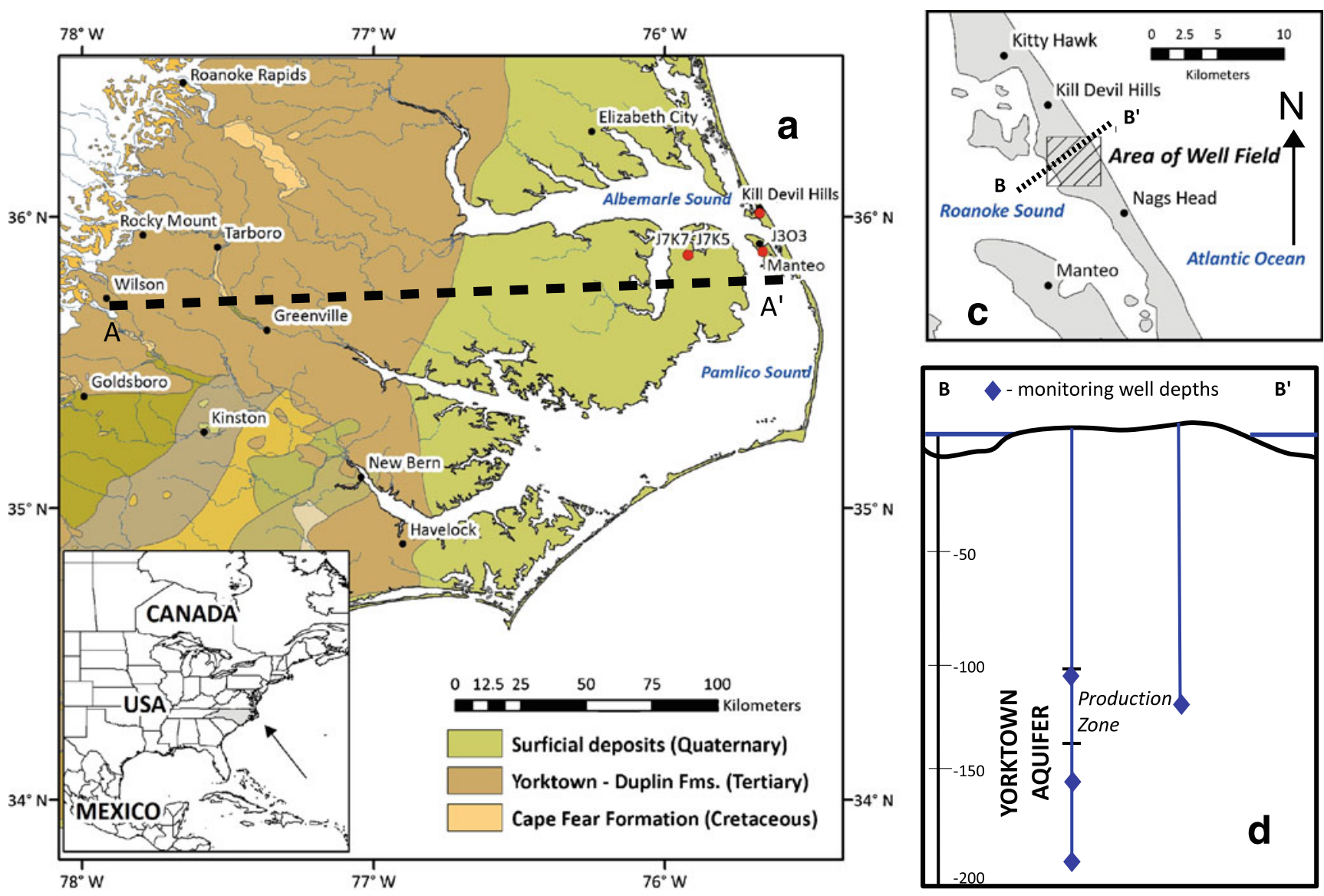

Elevation $(m)$

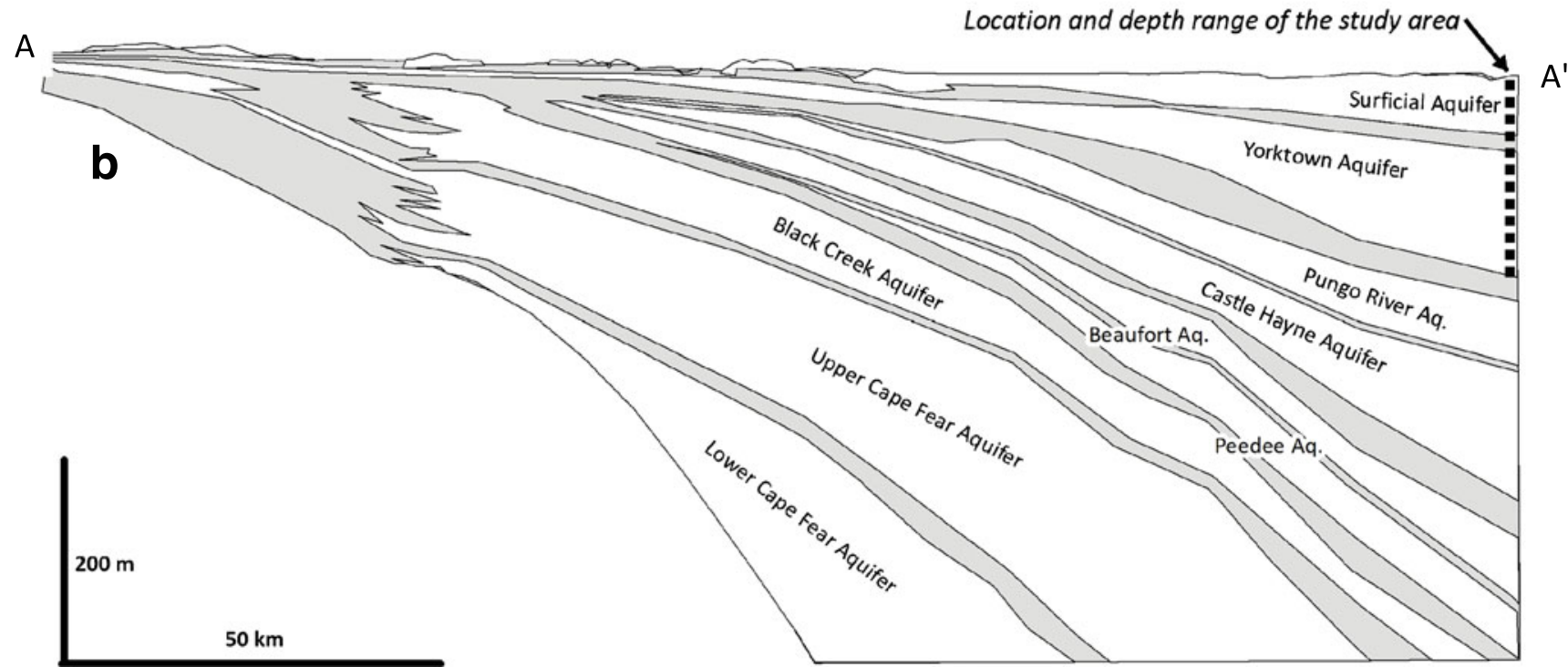

Fig. 2 Map and cross sections showing location of the study site and depths of wells sampled: a Geologic map based on North Carolina Geological Survey (1985) showing locations of wells $J 3 O 3, J 7 K 5$, and $J 7 K 7$; b Schematic cross section of the North Carolina Coastal Plain modified from Winner and Coble (1996; plate 7); c Inset map showing location of Kill Devil Hills well field, where all other wells were sampled; and d Schematic diagram indicating approximate depths of wells sampled within the Yorktown aquifer (interval labeled Production Zone indicates the screen length of high-capacity production wells) 


\section{Materials and methods}

Water samples were collected from four production wells, screened at approximately $90-120 \mathrm{~m}$ depth; three nested monitoring wells adjacent to a production well (depth 95-190 m; Fig. 2d); two coastal monitoring wells seaward from the production well field (depth $\sim 120 \mathrm{~m}$ ); and seven points within the RO desalination plant at Kill Devil Hills, Dare County, North Carolina (Table 1). In addition to the wells in the Kill Devil Hills area, three monitoring wells (depth $24-67 \mathrm{~m}$ ) on the mainland and near the town of Manteo on Roanoke Island (Fig. 2a) were sampled at sites maintained by the North Carolina Division of Water Resources. These three wells are shallower than the wells at Kill Devil Hills, chosen to represent shallow recharging waters away from possible marine sources, and thus may not represent the same stratigraphic level of the Yorktown aquifer. Monitoring wells were sampled after a period of continuous pumping to remove stagnant water. $\mathrm{pH}$, electrical conductivity, dissolved oxygen, and temperature were measured in water samples on site (Table 1). The samples were returned to Duke University for the analysis of major and trace elements coupled with boron and stable oxygen and hydrogen isotopes. Concentrations of $\mathrm{B}$, As, and $\mathrm{Sr}$ were determined by inductively coupled plasma-mass spectrometry calibrated using NIST $1643 \mathrm{e}$ trace element solution. Arsenic concentrations were corrected for chloride interference by the equivalent analyte concentration method (Taylor 2001). Ca, Mg, and $\mathrm{Na}$ concentrations were determined by direct current plasma spectrometry and potassium concentration was determined by flame atomic absorption spectrometry. Anion (chloride, sulfate, and bromide) concentrations were measured by ion chromatography. Effective detection limits and analytical precision vary by dilution factors (B $0.2-10 \mu \mathrm{g} / \mathrm{L}$, As $0.01-0.6 \mu \mathrm{g} / \mathrm{L}$ ). Bicarbonate concentrations were determined by titration to $\mathrm{pH}$ 4.5. Oxygen and hydrogen isotope ratios were determined in the Duke Environmental Isotope Laboratory by injection of $1 \mu \mathrm{L}$ samples from a gas-tight syringe into a ThermoFinnigan thermochemical analyzer, using $\mathrm{H}_{2}$ and $\mathrm{CO}$ gas peaks analyzed for isotope ratios with a ThermoFinnigan Delta + XL isotope ratio mass spectrometer and normalized against V-SMOW and V-SLAP. Precision is approximately $0.3 \%$ for $\delta^{2} \mathrm{H}$ and $0.1 \%$ for $\delta^{18} \mathrm{O}$. Boron isotope ratios were determined by negative ion thermal ionization mass spectrometry using a Thermo Scientific TRITON thermal ionization mass spectrometer at Duke University. Filtered water samples were treated by $\mathrm{H}_{2} \mathrm{O}_{2}$ oxidation, then $\sim 2 \mathrm{ng}$ of $\mathrm{B}$ was loaded onto outgassed rhenium filaments in a synthetic seawater solution containing $\mathrm{Na}, \mathrm{Mg}, \mathrm{Ca}$, and $\mathrm{K}$ from high-purity single-element standard solutions in a laminar-flow hood with B-free filters (Dwyer and Vengosh 2008). Ratios are normalized to the NIST 951 standard and reported as $\delta^{11} \mathrm{~B}$. Repeated analysis of NIST 951 and seawater yielded average ${ }^{11} \mathrm{~B} /{ }^{10} \mathrm{~B}$ of $4.0058(1 \sigma=0.0011$ or $0.3 \%, n=62)$ and $4.1630(1 \sigma=$ $0.0025, n=17 ; \delta^{11} \mathrm{~B}=39.2 \pm 0.6 \%$ ) , respectively.

\section{Results and discussion}

\section{Salinization of groundwater in the Yorktown aquifer}

Groundwater from shallow monitoring wells exhibits relatively low salinity relative to the deep monitoring wells with chloride content of $8,200-9,900 \mathrm{mg} / \mathrm{L}$ (Fig. 3; Table 1). The Dare County RO desalination plant uses saline groundwater from several production wells at intermediate depth (Fig. 2d, Table 1). Since the installation of these production wells, a total volume of $70 \times 10^{6} \mathrm{~m}^{3}$ has been extracted with a pumping rate in the range of $0.2-0.5 \times 10^{6} \mathrm{~m}^{3} /$ year per well. Operation of the production wells since the late $1980 \mathrm{~s}$ has coincided with a general decline in the water table as measured in the monitoring wells (Fig. 4a): from a depth of $10-12 \mathrm{~m}$ in the early $1990 \mathrm{~s}$ to a depth range of 13-16 $\mathrm{m}$ during the late 2000s. This suggests that pumping rates have exceeded the natural replenishment of this aquifer. The salinity in these wells has also increased since the installation of the pumping. Historic data for the production wells show that the chloride content has increased from an initial concentration of $970 \mathrm{mg} / \mathrm{L}$ in August 1989 to approximately 2,500 mg/L by 2009 (Fig. 4). During the first five years of pumping, the salinity increase rate was high $(\sim 190 \mathrm{mg} / \mathrm{L}$ per year), followed by a lower salinization rate $(\sim 45 \mathrm{mg} / \mathrm{L}$ per year), indicated by the leveling of the chloride concentration trend (Fig. 4b).

\section{Tracing the source of the salinity by geochemical and isotope techniques}

In order to evaluate the origin of salinization of the production wells, the geochemical composition of saline groundwater at different depths in the Yorktown aquifer was investigated (Table 1). First, ion ratios, $\delta^{2} \mathrm{H}$, and $\delta^{18} \mathrm{O}$ are consistent with mixing between shallow freshwater and deep saline water. Mixing with upcoming saline water is supported by (1) variations of $\delta^{2} \mathrm{H}$ and $\delta^{18} \mathrm{O}$ (Fig. 5) that indicate a mixing relationship between seawater-like saline groundwater $\left(\delta^{2} \mathrm{H}\right.$ and $\delta^{18} \mathrm{O}$ here approximated at $0 \%$ although analysis of North Carolina coastal surface water indicates median $\delta^{18} \mathrm{O}$ of $+0.92 \% ; n=40$; Schmidt et al. 1999) and low-salinity groundwater derived from local recharge $\left(\delta^{2} \mathrm{H} \approx-20 \% ; \delta^{18} \mathrm{O} \approx-4.5 \%\right.$; Table 2$)$; and (2) a constant $\mathrm{Br} / \mathrm{Cl}$ ratio near the seawater value of $1.5 \times 10^{-3}$ (Fig. 6). Water from the production zone wells is consistent with mixing between the deep and shallow groundwater, based on $\mathrm{Br} / \mathrm{Cl}, \mathrm{Na} / \mathrm{Cl}, \mathrm{Mg} / \mathrm{Cl}, \mathrm{Ca} / \mathrm{Cl}$, and $\mathrm{Sr} / \mathrm{Cl}$ ratios, although these ion ratios are somewhat modified by cation exchange. For a hypothetical vertical mixture between wells $1-310$ and $1-610$, ion ratios consistently indicate that inputs of $20-25 \%$ deep saline water can explain the chemistry of produced water (Fig. 6).

Secondly, the nature of the deep saline water that contributes to the Kill Devil Hills well field was examined. Evaluating the source of the saline component (e.g., seawater, old modified seawater, brackish water, or 


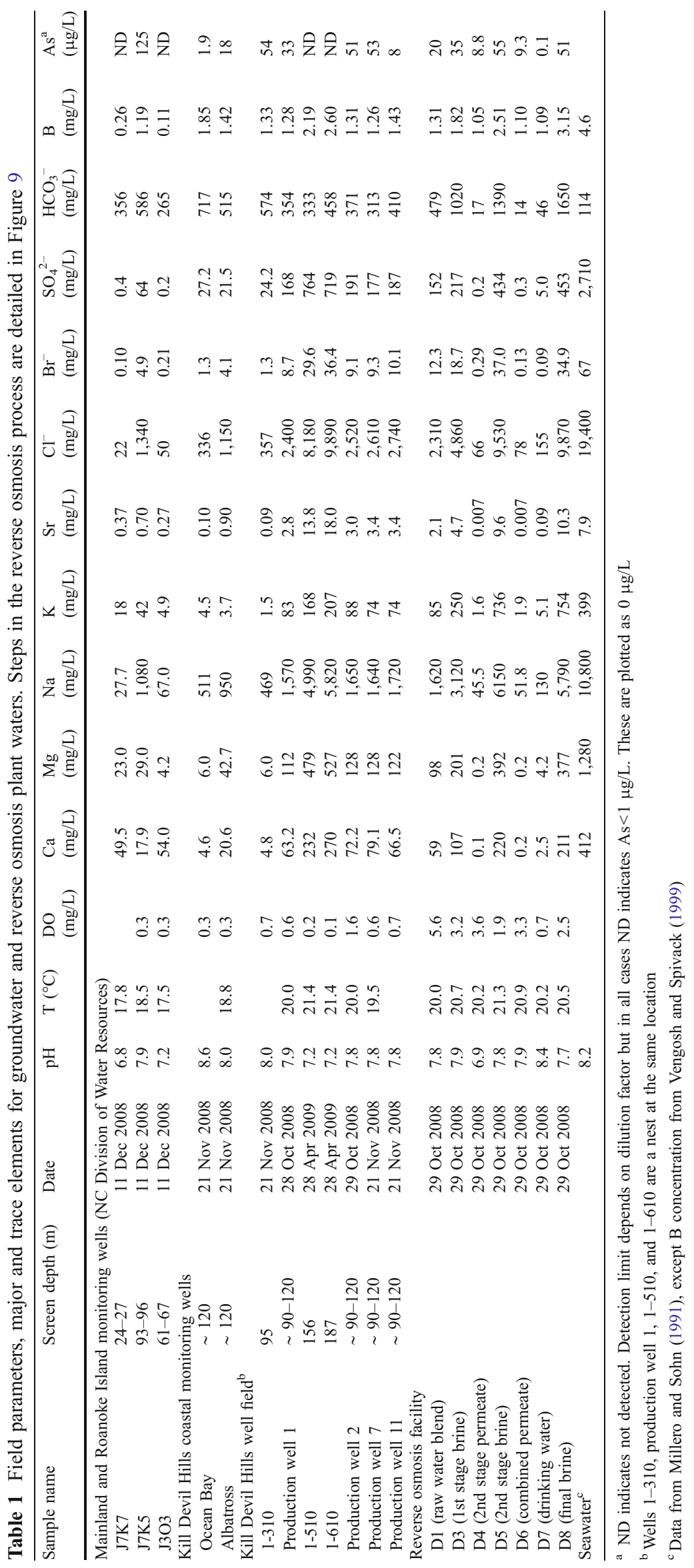




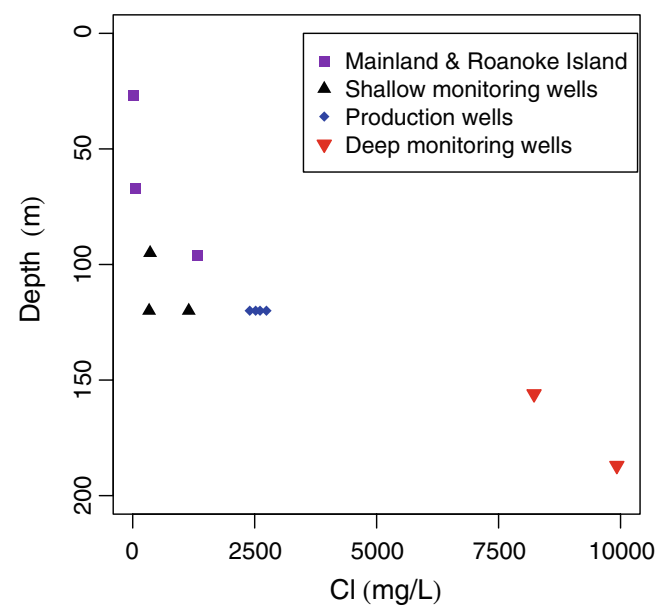

Fig. 3 Relationship between chloride concentration and depth in studied groundwater arranged by location, depth, and type of wells brine) affecting the Kill Devil Hills well field could have implications for predicting future salinity trends. The lowsalinity groundwater in shallow wells at Kill Devil Hills (1-310, Albatross, and Ocean Bay; Table 2) exhibits high $\mathrm{Na} / \mathrm{Cl}(>1)$ and $\mathrm{B} / \mathrm{Cl}\left(>2 \times 10^{-3}\right)$, low $\mathrm{Mg} / \mathrm{Cl}$ and $\mathrm{Ca} / \mathrm{Cl}$ ratios, and low $\delta^{11} \mathrm{~B}(23-29 \%)$ relative to the composition of modern seawater $\left(\delta^{11} \mathrm{~B}=39 \%\right.$; $\mathrm{B} / \mathrm{Cl}=8 \times 10^{-4}$; Figs. 6 and 7). In contrast, the deep groundwater is saline and has some geochemical properties that resemble seawater (e.g., $\mathrm{Na} / \mathrm{Cl}$ close to the seawater value of $0.86 ; \mathrm{Br} / \mathrm{Cl}$ close to the seawater value of $1.5 \times 10^{-3}$; Table 2 ). This composition suggests reverse base-exchange reactions, in which $\mathrm{Ca}$ - and $\mathrm{Mg}$-bearing recharge interacts with marine clays in which the exchange sites are occupied by $\mathrm{Na}$ due to prior contact with seawater. In a reverse base-exchange reaction, $\mathrm{Ca}^{2+}$ and $\mathrm{Mg}^{2+}$ are lost from the groundwater to the solids in exchange for $\mathrm{Na}^{+}$, resulting in $\mathrm{Na}$ enrichment

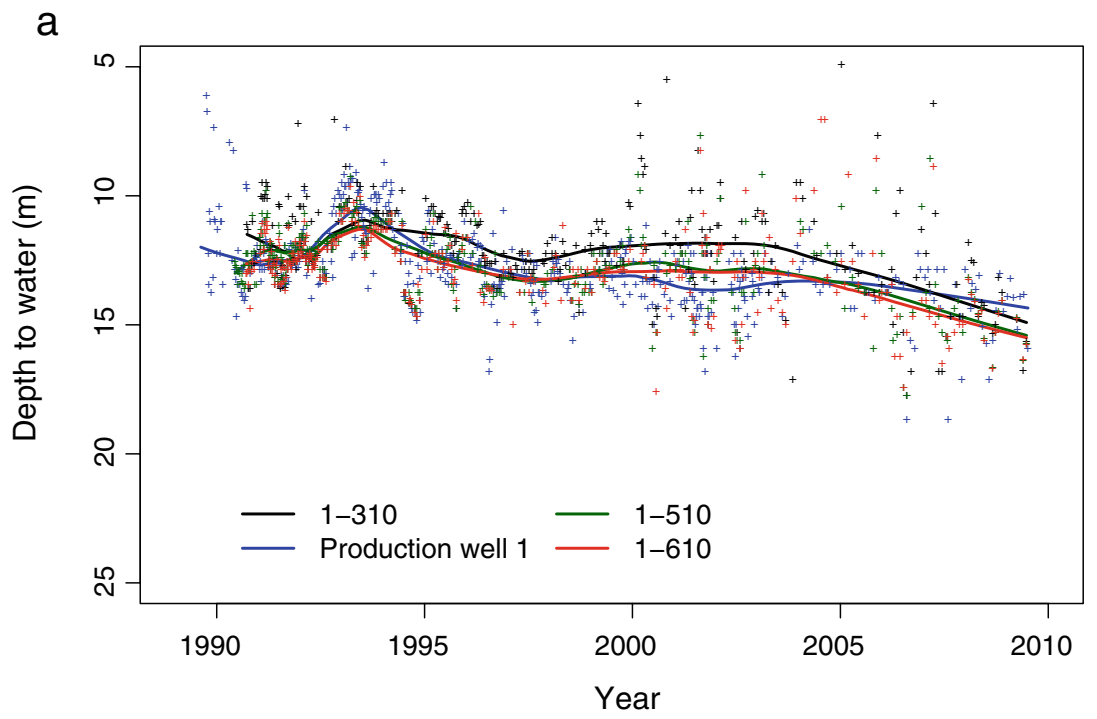

b

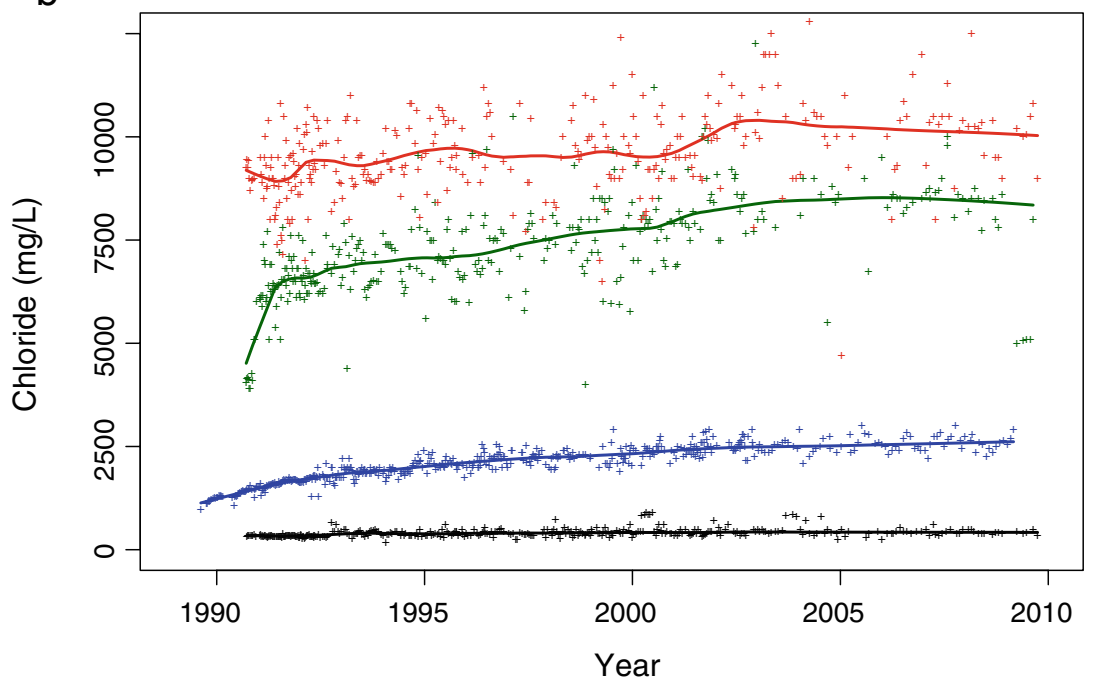

Fig. 4 Historical water data for production well 1 and adjacent monitoring wells (1-310, 1-510, 1-610) from 1989 through 2009: a water level measurements; b chloride concentrations. Data provided by Dare County Water Department. Trend lines calculated using LOWESS method in which smoothing is controlled by the nearest $20 \%$ of data points (R Development Core Team 2009) 
a

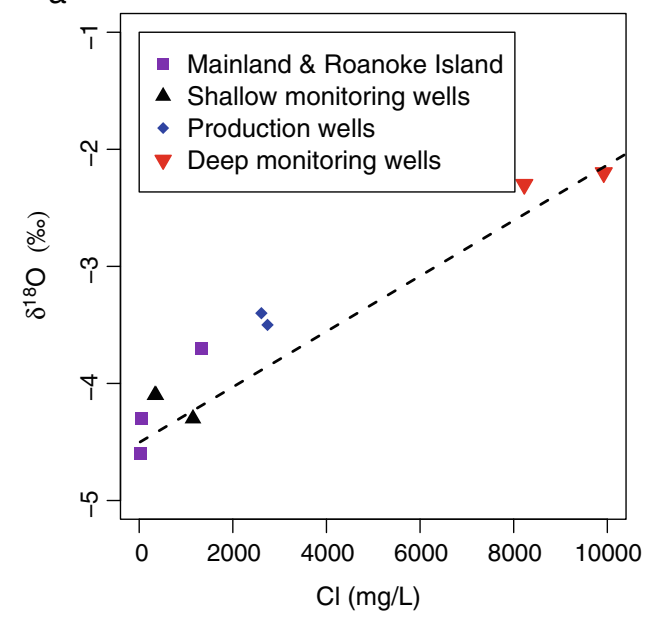

b

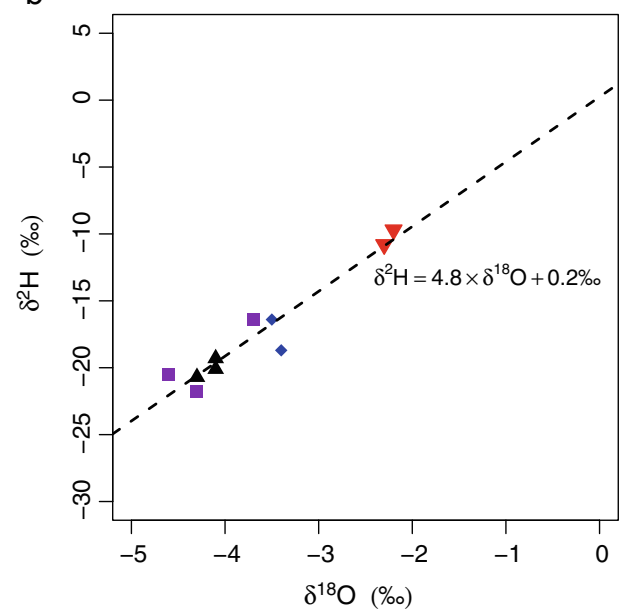

Fig. 5 a Oxygen and $\mathbf{b}$ hydrogen isotope ratios in groundwater plotted along possible mixing trends. In a the dashed line represents hypothetical mixing of fresh locally recharged groundwater $\left(20 \mathrm{mg} / \mathrm{L} \mathrm{Cl}, \delta^{2} \mathrm{H} \approx-20 \%\right.$ o, $\delta^{18} \mathrm{O} \approx-4.5 \%$ ) with a seawater-like saline groundwater $\left(\sim 19,000 \mathrm{mg} / \mathrm{L} \mathrm{Cl}, \delta^{2} \mathrm{H}\right.$ and $\delta^{18} \mathrm{O} \approx 0 \%$ ). In $\mathbf{b}$ the dashed line represents a linear regression of the $\delta^{2} \mathrm{H}$ and $\delta^{18} \mathrm{O}$ data. Note the $y$-intercept value of $\delta^{2} \mathrm{H} \approx 0 \%$, indicating a mixing relationship with seawater-like saline water rather than meteoric water that would exhibit deuterium excess

in the residual groundwater (Chapelle and Knobel 1983; Knobel et al. 1998). Reverse base-exchange reactions can also explain the relatively high $\mathrm{B} / \mathrm{Cl}$ and low $\delta^{11} \mathrm{~B}$ values (Fig. 7) that are consistent with the composition expected from boron desorption from clay minerals (Spivack et al. 1987). In contrast, in direct base-exchange reactions that characterize seawater intrusion zones, boron is retained by adsorption onto clay minerals, resulting in high $\delta^{11} \mathrm{~B}$ and low $\mathrm{B} /$ $\mathrm{Cl}$ in the residual groundwater relative to seawater values (Jones et al. 1999; Vengosh and Spivack 1999; Vengosh 2003). Although $\mathrm{Ca} / \mathrm{Cl}$ and $\mathrm{Sr} / \mathrm{Cl}$ ratios exceed seawater values in the deep saline groundwater, as is seen in seawater intrusion zones (Nadler et al. 1980; Vengosh et al. 2002; Andersen et al. 2005; Sivan et al 2005), $\mathrm{Mg} / \mathrm{Cl}$ is significantly depleted relative to the seawater ratio. Together, these ratios imply that mixing and divalent-for-monovalent exchange cations cannot completely explain the $\mathrm{Ca}$ and $\mathrm{Mg}$ concentrations in the groundwater system;

Table 2 Ion $(\mathrm{mol} / \mathrm{mol})$ and isotopic ratios of groundwater and reverse osmosis plant water

\begin{tabular}{|c|c|c|c|c|c|c|c|c|c|}
\hline Sample name & $\mathrm{Na} / \mathrm{Cl}$ & $\mathrm{Mg} / \mathrm{Cl}$ & $\mathrm{Ca} / \mathrm{Cl}$ & $\begin{array}{l}\mathrm{Sr} / \mathrm{Cl} \\
\left(\times 10^{-4}\right)\end{array}$ & $\mathrm{SO}_{4}{ }^{2-} / \mathrm{Cl}$ & $\begin{array}{l}\mathrm{B} / \mathrm{Cl} \\
\left(\times 10^{-3}\right)\end{array}$ & $\begin{array}{l}\delta^{11} \mathrm{~B} \\
(\% \mathrm{o})\end{array}$ & $\begin{array}{l}\delta^{2} \mathrm{H} \\
(\%)\end{array}$ & $\begin{array}{l}\delta^{18} \mathrm{O} \\
(\%)\end{array}$ \\
\hline \multicolumn{10}{|c|}{ Mainland and Roanoke Island monitoring wells } \\
\hline $\mathrm{J} 7 \mathrm{~K} 7$ & 1.93 & 1.52 & 2.16 & 22 & 0.007 & 40 & 20.9 & -20.5 & -4.6 \\
\hline $\mathrm{J} 7 \mathrm{~K} 5$ & 1.24 & 0.032 & 0.012 & 2.1 & 0.018 & 2.9 & 33.4 & -16.4 & -3.7 \\
\hline $\mathrm{J} 3 \mathrm{O} 3$ & 2.08 & 0.12 & 0.88 & 68 & 0.001 & 7.3 & & -21.8 & -4.3 \\
\hline \multicolumn{10}{|c|}{ Kill Devil Hills coastal monitoring wells } \\
\hline Ocean Bay & 2.35 & 0.026 & 0.012 & 1.2 & 0.030 & 18 & 24.8 & -20.1 & -4.1 \\
\hline Albatross & 1.28 & 0.054 & 0.016 & 3.2 & 0.007 & 4.1 & 29.8 & -20.7 & -4.3 \\
\hline \multicolumn{10}{|c|}{ Kill Devil Hills well field } \\
\hline $1-310$ & 1.76 & 0.024 & 0.010 & 1.0 & 0.025 & 12 & 22.6 & & \\
\hline Production well 1 & 1.01 & 0.071 & 0.023 & 4.7 & 0.026 & 1.8 & 25.8 & & \\
\hline $1-510$ & 0.94 & 0.091 & 0.025 & 6.8 & 0.035 & 0.88 & 34.5 & $-10.8^{\mathrm{a}}$ & $-2.3^{\mathrm{a}}$ \\
\hline $1-610$ & 0.91 & 0.083 & 0.024 & 7.4 & 0.027 & 0.86 & 34.7 & $-9.7^{\mathrm{a}}$ & $-2.2^{\mathrm{a}}$ \\
\hline Production well 2 & 1.01 & 0.072 & 0.025 & 4.8 & 0.028 & 1.7 & 27.9 & & \\
\hline Production well 7 & 0.97 & 0.081 & 0.027 & 5.3 & 0.025 & 1.6 & 27.3 & -18.7 & -3.4 \\
\hline Production well 11 & 0.97 & 0.071 & 0.021 & 5.0 & 0.025 & 1.7 & 28.8 & -16.7 & -3.5 \\
\hline \multicolumn{10}{|c|}{ Reverse osmosis facility } \\
\hline D1 & 1.08 & 0.062 & 0.022 & 3.7 & 0.024 & 1.9 & 29.1 & & \\
\hline D3 & 0.99 & 0.060 & 0.019 & 3.9 & 0.016 & 1.2 & 28.3 & & \\
\hline D4 & 1.06 & 0.005 & 0.002 & 0.43 & 0.001 & 51.9 & 28.1 & & \\
\hline D5 & 1.00 & 0.060 & 0.020 & 4.1 & 0.017 & 0.86 & 28.7 & & \\
\hline D6 & 1.02 & 0.004 & 0.002 & 0.47 & 0.001 & 46 & 28.3 & & \\
\hline D7 & 1.29 & 0.040 & 0.014 & 2.3 & 0.012 & 23 & 29.2 & & \\
\hline D8 & 0.91 & 0.056 & 0.019 & 4.2 & 0.017 & 1.0 & 32.6 & & \\
\hline Seawater & 0.86 & 0.096 & 0.019 & 1.6 & 0.052 & 0.78 & $39^{\mathrm{b}}$ & & \\
\hline
\end{tabular}

${ }^{\text {a }}$ From samples collected 20-21 Nov 2008

${ }^{\mathrm{b}}$ Vengosh and Spivack (1999) 

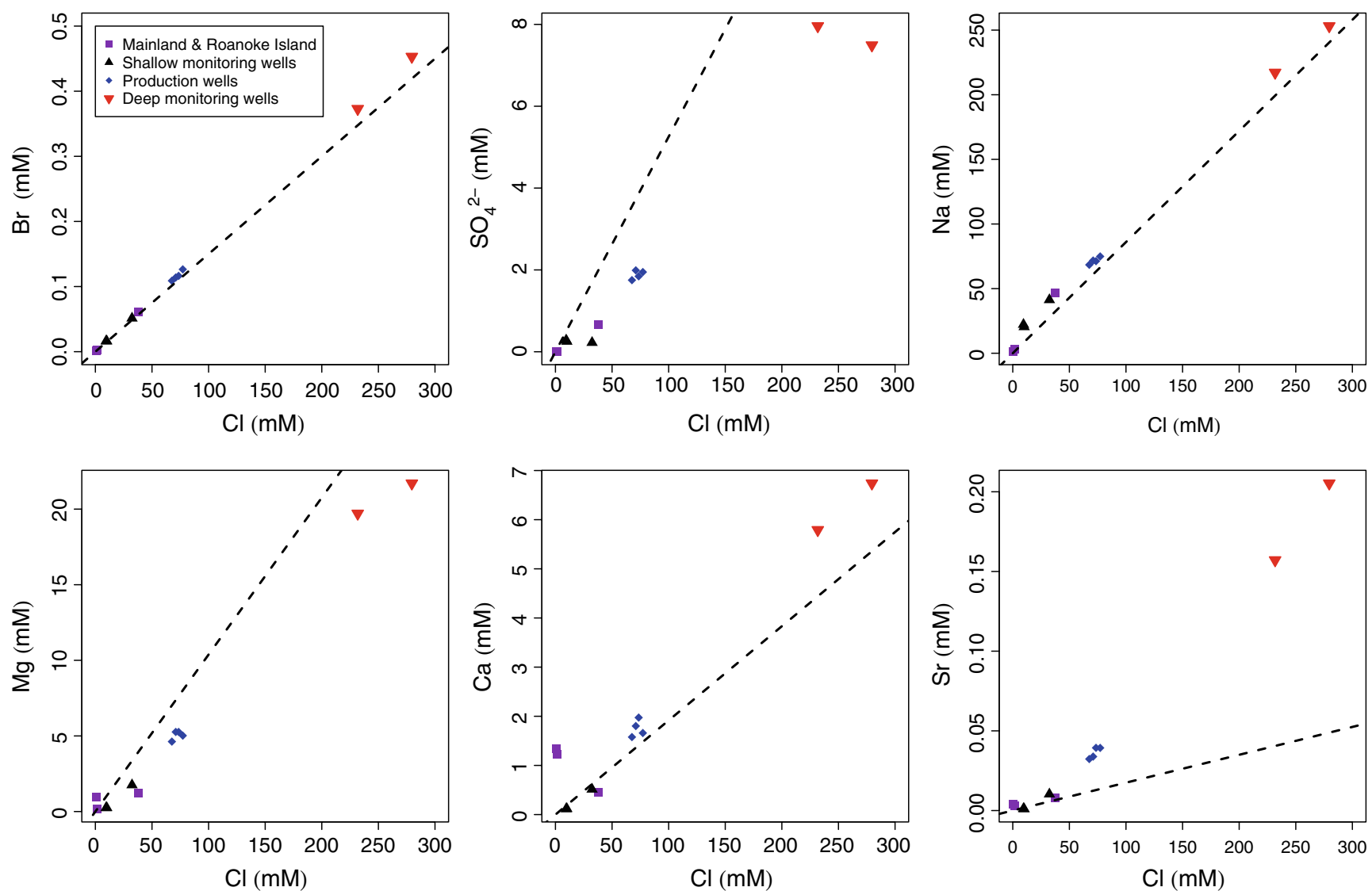

Fig. 6 Relationships between chloride and major ion concentrations in the investigated groundwater. Dashed lines represent hypothetical dilution of seawater. Note that the compositions of the production wells show a mixing relationship between deep and shallow groundwater representing about $20-25 \%$ input of deep, saline water

some other phenomenon such as carbonate equilibrium may be necessary. The highest $\mathrm{Ca} / \mathrm{Cl}$ and $\mathrm{Mg} / \mathrm{Cl}$ ratios in the study area are seen in shallow wells inland from the Kill Devil Hills well field (J3O3 and J7K7; Table 2) that are less affected by reverse cation exchange due to the freshening impact of recharge. Overall, ion ratios and $\delta^{11} \mathrm{~B}$ values suggest that the salinity of the pumping wells is derived from mixing of modified and apparently old seawater with local recharge, and not modern seawater intrusion. This mixing relationship is also modified by reverse baseexchange reactions and boron desorption in the shallow, fresh portion of the aquifer. Mixing with old seawater at depth is consistent with previous studies of the Atlantic Coastal Plain (see section Hydrogeologic setting), and can also explain the relatively low rate of
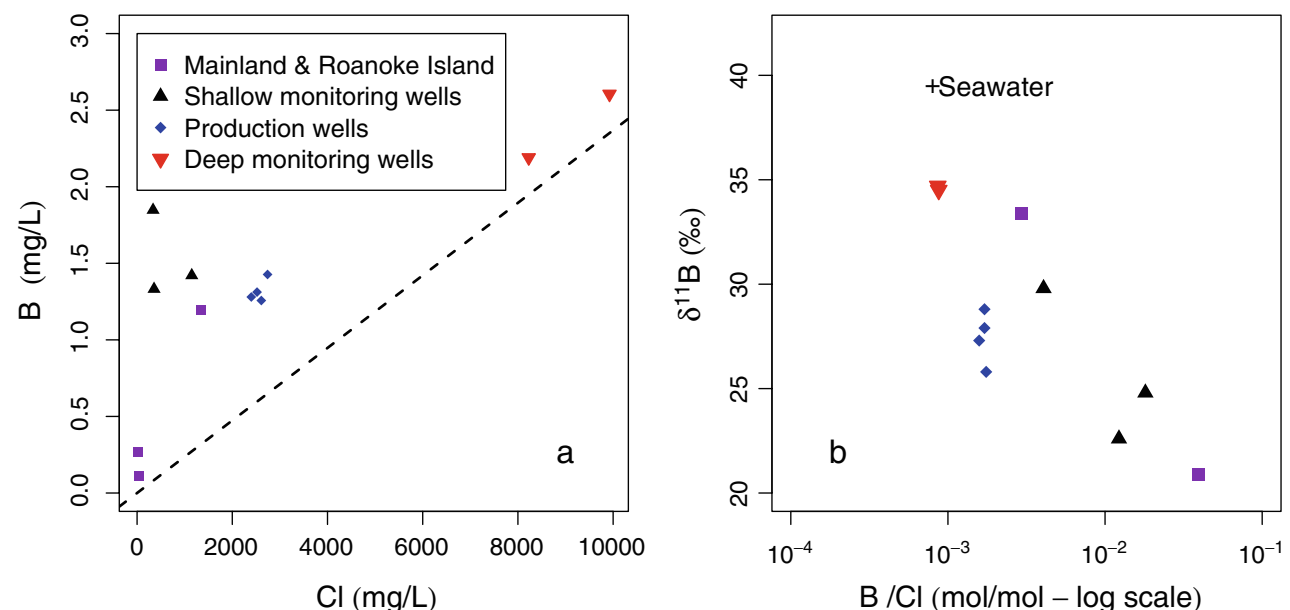

Fig. 7 Relationship between a boron and chloride contents and $\mathbf{b} \delta^{11} \mathrm{~B}$ and $\mathrm{B} / \mathrm{Cl}$ ratios $(\log$ scale) in the investigated groundwater. Note that studied groundwater samples have higher $\mathrm{B} / \mathrm{Cl}$ and lower $\delta^{11} \mathrm{~B}$ values relative to seawater 
salinization of the pumping wells (Fig. 4b), compared to rapid, exponential salinization rates that characterize seawater intrusion fronts in over-exploited coastal aquifers (Vengosh 2003).

\section{Arsenic, boron, and future salinity trends}

In addition to the overall salinity in the produced water, levels of naturally occurring contaminants affect the suitability of saline groundwater for reverse osmosis desalination. The wells in the production zone contain 8-53 $\mu \mathrm{g} / \mathrm{L}$ arsenic and $1.3-1.4 \mathrm{mg} / \mathrm{L}$ boron (Table 1; Fig. 8). As addressed in the following discussion, the removal of these contaminants is relatively ineffective in reverse osmosis desalination, and they may remain at elevated concentrations in post-RO water. Thus, future increases of natural contaminants in groundwater as salinization proceeds could affect the quality of water produced by the RO system. Extrapolation of previous salinity trends suggests potential future levels of salinity and boron. The average rate of groundwater salinization in the production wells from 1994 to 2009 was $\sim 45 \mathrm{mg} / \mathrm{L}$ chloride per year (Fig. 4b). Extrapolating a linear salinization rate for the next 20 years implies a $\sim 35 \%$ increase in salinity. Thus, the current chloride content could increase to about $3,400 \mathrm{mg} / \mathrm{L}$ in 2030 and to about $4,300 \mathrm{mg} / \mathrm{L}$ in 2050 . However, the recent leveling of the salinization trend (Fig. 4b) implies that a linear extrapolation of the salinization rate may be excessive, and that a near-equilibrium condition may be reached that is significantly less saline than seawater but represents a larger proportion of the deep brackish water as the shallow freshwater is depleted. Because boron concentration is associated to some degree with chloride concentration and depth (Fig. 8), the expected rise in salinity may be associated with an additional increase in the boron content of the groundwater blend. The boron content in the produced groundwater could increase to approximately $2 \mathrm{mg} / \mathrm{L}$ in 2050 . In contrast to boron, the results indicate that the deep and saline groundwater exhibits lower As concentration than the shallow and less saline groundwater. The high As occurrence is apparently limited to groundwater within certain depth intervals of the aquifer as a result of local water-rock interaction with a solid-phase arsenic source that varies spatially rather than being a systematic phenomenon associated with salinity (Fig. 8). The data suggest that increased mixing of the deep saline component should not cause net As transport into the production zone of the aquifer.

\section{Selective rejection in $\mathbf{R O}$ desalination of saline groundwater}

The desalination plant in Kill Devil Hills, Dare County is composed of a cascade of two RO membrane systems and a post-treatment system specifically designed for arsenic removal (Fig. 9). A groundwater blend from the pumping wells is used as a water source. At the first stage, the groundwater is pressurized through $\mathrm{RO}$ stage $\mathrm{A}$. The brine then flows through RO stage $\mathrm{B}$, and permeates (treated water) from these two stages are mixed (sample D6; Table 1) before they are treated further for arsenic in the post-RO facility and are ultimately mixed with untreated groundwater (to increase hardness) for distribution. The residual brine is discharged to the ocean. Table 1 presents the chemical results for different constituents in permeate and concentrate (residual brine) solutions. The data show that in spite of the significant increase in salinity in the raw water during 20 years of operation, the RO system strongly rejects divalent and monovalent ions with removal efficiencies of $96-99 \%$ (Table 3). In contrast, a

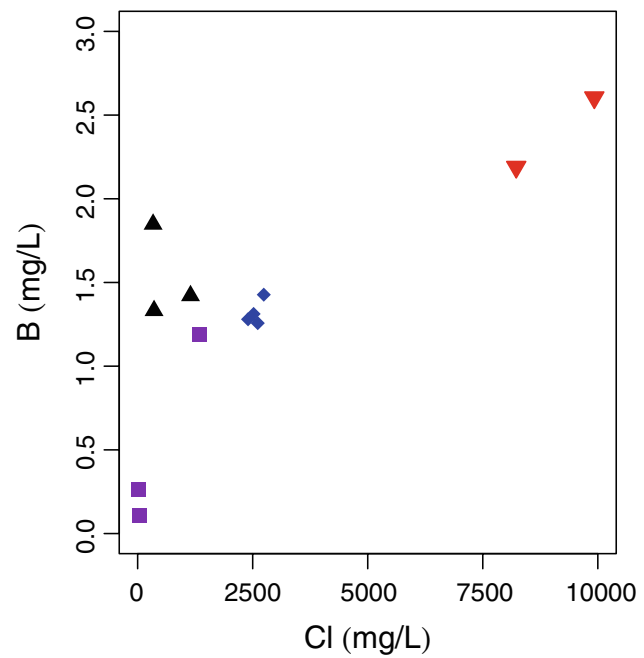

b

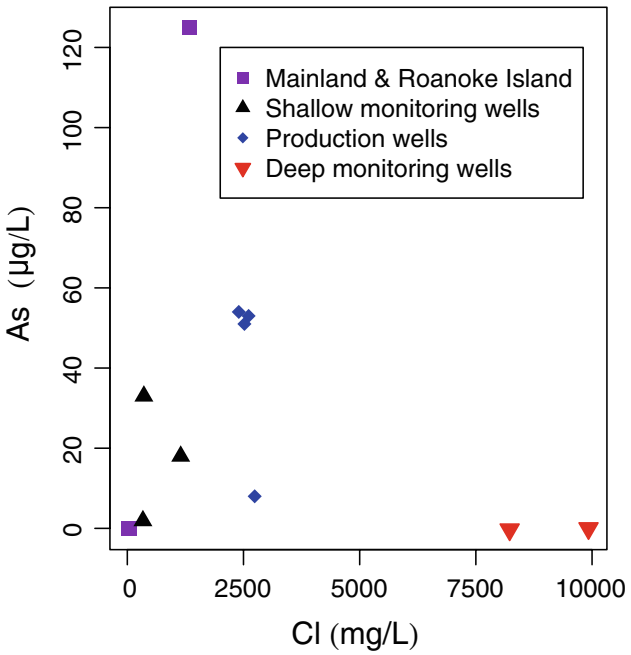

Fig. 8 a Boron and $\mathbf{b}$ arsenic in relation to chloride concentrations in the investigated groundwater. Note that while boron is generally associated with chloride, arsenic is not, particularly for the deep and saline groundwater. This implies that further salinization may not induce an increase in As concentration 


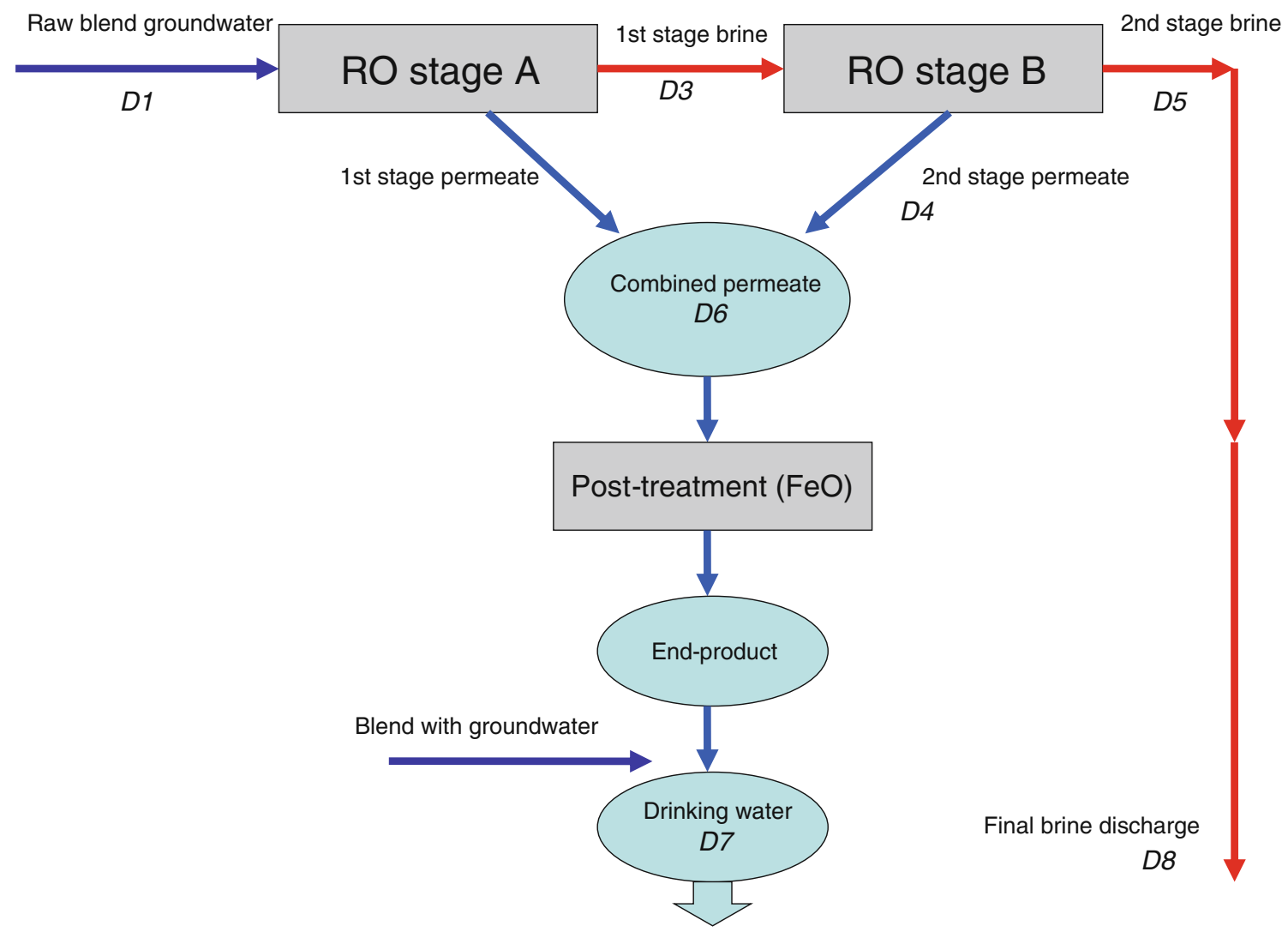

Fig. 9 Schematic diagram of the Dare County North RO desalination water plant at Kill Devil Hills indicating samples collected at different water treatment steps

the removal of boron and arsenic by the RO membrane is significantly lower (16-42\% and $54-75 \%$, respectively). Consequently, the concentrations of boron $(1.1 \mathrm{mg} / \mathrm{L})$ and arsenic $(9.3 \mu \mathrm{g} / \mathrm{L})$ in the combined permeate water (sample D6; Table 1) are near or exceed the EPA maximum contaminant level for arsenic $(10 \mu \mathrm{g} / \mathrm{L})$ and World Health Organization (WHO) recommendations $(0.5 \mathrm{mg} / \mathrm{L} \mathrm{B}$ and $10 \mu \mathrm{g} / \mathrm{L} \mathrm{As}$; WHO 2008). Other arsenic data from this system (Oreskovich and Watson 2003) are typically above $10 \mu \mathrm{g} / \mathrm{L}$. Boron concentrations are below the EPA Health Advisory, a US government recommendation (5 mg/L lifetime advisory; EPA 2008). In addition to these national and international advisories, six states in the USA, not including North Carolina, have adopted boron advisories between 0.6 and $1.0 \mathrm{mg} / \mathrm{L}$ (EPA 2008).

The relatively low rejection of boron from the RO membrane is related to the distribution of boron species and the mode of RO operation (Prats et al. 2000; Parks and Edwards 2005; Georghiou and Pashafidis 2007; Kloppmann et al. 2008; Cengeloglu et al. 2008; Ozturk et al. 2008; Mane et al. 2009). The data indicate that the second RO system removes almost $42 \%$ of boron (from
D3, the brine of the first stage, to D4, the second permeate; Fig. 9; Table 3), while overall removal performance is much lower $(16 \%)$, implying that the removal capacity of the first RO system is very low. In Dare County, the $\mathrm{pH}$ of the inflow groundwater is about 7.8, which is not highly modified by the RO process (Table 1 ). Under conditions of salinity of $\sim 5,000 \mathrm{mg} / \mathrm{L}$, temperature of $20^{\circ} \mathrm{C}$ (Table 1 ), and pressure of $\sim 18$ bars (the average RO feed pressure at Dare County), the dissociation constant of boric acid $\left(\mathrm{pk}_{\mathrm{B}}\right)$ is 8.97 (calculated from empirical values made by Dickson 1990 and Millero 1995), and thus at $\mathrm{pH}=7.8$, boron exists mostly in the form of uncharged boric acid (93\%; Fig. 10). Several studies have shown differential permeation of boron species through the RO membranes and that the uncharged boric acid is not rejected effectively like the other charged ions (Sagiv and Samiat 2004; Hyung and Kim 2006; Kloppmann et al. 2008; Mane et al. 2009). Consequently, the boron rejection is low and the $\mathrm{B} / \mathrm{Cl}$ molar ratios in the permeates $(0.02-0.05)$ are significantly higher than that of the raw groundwater and brines (0.00086-0.0019; Table 2). In contrast, the original $\delta^{11} \mathrm{~B}$

Table 3 Removal percentages of major and trace elements from the RO desalination plant at Kill Devil Hills. Steps in the reverse osmosis process are indicated in Figure 8

\begin{tabular}{|c|c|c|c|c|c|c|c|c|}
\hline Process & $\mathrm{B}$ & As & $\mathrm{Sr}^{2+}$ & $\mathrm{Na}^{+}$ & $\mathrm{K}^{+}$ & $\mathrm{Cl}^{-}$ & $\mathrm{Br}^{-}$ & $\mathrm{SO}_{4}{ }^{2-}$ \\
\hline$\% \mathrm{RO}$ removal of second RO stage (D3-D4) & 42.4 & 74.9 & 99.9 & 98.5 & 99.5 & 98.6 & 98.5 & 98.4 \\
\hline$\%$ RO removal of combined stages (D1-D6) & 16.0 & 53.5 & 99.9 & 97.0 & 97.7 & 96.7 & 98.5 & 95.0 \\
\hline
\end{tabular}




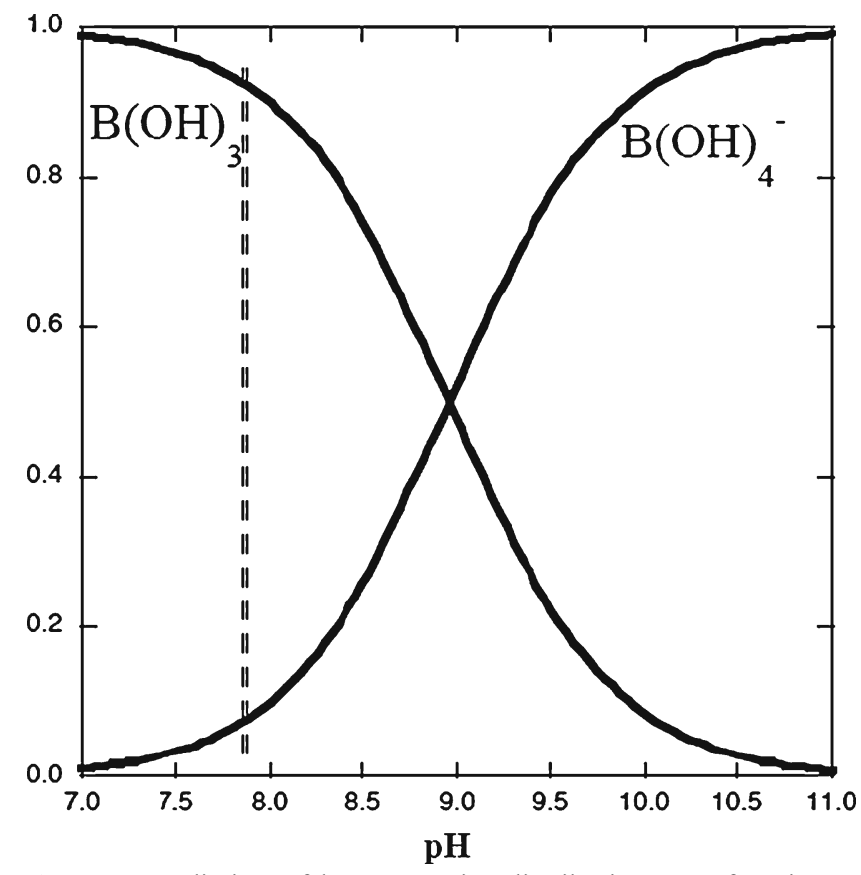

Fig. 10 Prediction of boron species distribution as a function of $\mathrm{pH}$. Calculations were based on modeling boric acid dissociation at salinity of $5,000 \mathrm{mg} / \mathrm{L}$, temperature of $20^{\circ} \mathrm{C}$, and pressure of 18 bars (combined $\left.\mathrm{pk}_{\mathrm{B}}=8.97\right)$. Under conditions of $\mathrm{RO}$ desalination $(\mathrm{pH}=$ 7.8, see dashed line), $93 \%$ of boron is in the form of uncharged boric acid

value of the source groundwater is not significantly modified (Table 3 ) due to the predominance of boric acid in the feed water (Fig. 10) and the lack of isotopic fractionation that could be induced by the separation of boron species (Kloppmann et al. 2008).

In addition to boron, arsenic rejection in the RO process is poor. The production wells contain As concentrations from 8 to $54 \mu \mathrm{g} / \mathrm{L}$ and the rejection in the RO process is only $\sim 54-75 \%$ (Table 3 ). Low rejection of As has been reported previously in RO systems (Oreskovich and Watson 2003; Pawlak et al. 2006; George et al. 2006; Moore et al. 2008; Walker et al. 2008; Geucke et al. 2009) and depends on the prevalence of charged As species. Arsenic speciation in water depends on oxidation state and $\mathrm{pH}$. Under reducing conditions, arsenic occurs as arsenite (As(III)) in which the uncharged $\mathrm{H}_{3} \mathrm{AsO}_{3}{ }^{0}$ is the predominant species at $\mathrm{pH}$ below 9. Under oxic conditions, arsenate $(\mathrm{As}(\mathrm{V}))$ species are dominant, particularly the monovalent species $\mathrm{H}_{2} \mathrm{AsO}_{4}^{-}(\mathrm{pH}<6.5)$ and the divalent species $\mathrm{HAsO}_{4}{ }^{2-}(\mathrm{pH}>6.5)$. Consequently, RO rejection for the charged $\mathrm{As}(\mathrm{V})$ in oxygenated water is more effective (Oreskovich and Watson 2003; Pawlak et al. 2006; George et al. 2006; Moore et al. 2008; Walker et al. 2008; Geucke et al. 2009). In the production wells, dissolved oxygen concentration is typically below $1 \mathrm{mg} / \mathrm{L}$ (Table 1). Thus, essentially anoxic conditions support the presence of significant arsenic (III); previous research at the site has indicated that both arsenic (III) and arsenic (IV) species are present in untreated water from the Kill Devil Hills well field (As(III) $<0.5-32 \mu \mathrm{g} / \mathrm{L} ; \mathrm{As}(\mathrm{V})<0.5-88 \mu \mathrm{g} / \mathrm{L}$; Oreskovich and Watson 2003). This anoxic water is not aerated throughout the RO process in order to avoid oxidation and scaling of the membrane system with iron and other oxides, and reported dissolved oxygen values of reverse osmosis process water (Table 1) are maximum values, subject to aeration during sampling. The presence of the uncharged $\mathrm{H}_{3} \mathrm{AsO}_{3}{ }^{0}$ results in the overall low As rejection. The resulting As concentrations, variable but typically exceeding $10 \mu \mathrm{g} / \mathrm{L}$ in the post-RO permeate, are dominated by As(III) (Oreskovich and Watson 2003) and necessitated a post-treatment procedure (Fig. 9) composed of granulated ferric oxide with high adsorption capacity for As. The results indicate a significant $(\sim 99 \%)$ rejection of As in the post-treatment process, which reduces the As concentration $(0.1 \mu \mathrm{g} / \mathrm{L})$ to far below the EPA maximum contaminant level of $10 \mu \mathrm{g} / \mathrm{L}$. The brine that is produced from the Dare County RO plant contains total dissolved solids of $19,000 \mathrm{mg} / \mathrm{L}$ and is characterized by relatively high boron and arsenic concentrations of $3.2 \mathrm{mg} / \mathrm{L}$ and $51 \mu \mathrm{g} / \mathrm{L}$, respectively.

In light of the expected increase in boron concentrations as salinity increases in the future, the overall poor RO boron rejection is expected to continue. Given the potential health effects of elevated boron in drinking water (European Union 1998; Weinthal et al. 2005; EPA 2008; WHO 2008), the relatively high boron content in the RO produced water could be reduced by additional post-treatment procedures for boron removal (Parks and Edwards 2005; Jacob 2007) and/or changes in RO operation conditions (e.g., high $\mathrm{pH}$; Sagiv and Samiat 2004; Hyung and Kim 2006; Kloppmann et al. 2008; Mane et al. 2009). However, future salinization is not expected to be associated with an increase in the As content of the blended groundwater, and the high rejection capacity of the post-treatment facility is expected to continue to be effective in removing As from the produced water.

\section{The suitability of saline groundwater in coastal aquifers for RO desalination}

In general, three types of saline groundwater could possibly occupy coastal aquifers: (1) saline water originated from direct seawater inland encroachment; (2) saline groundwater that evolved from residue of entrapped fossil seawater originated from past intrusion of seawater during high sea levels; and/or (3) displacement of saline groundwater from underlying and adjacent aquifers (Custodio 1997; Jones et al. 1999). Formation of a cone of depression in a coastal aquifer due to pumping the saline groundwater for desalination would cause a displacement of the saltwater front and salinization of the pumping wells. Yet the different types of saline groundwater would cause different responses in salinization rate and water composition, which would have direct implications for their potential use for RO desalination. Numerous studies have shown (Jones et al. 1999; Vengosh 2003 and references therein) that rapid inland seawater encroachment involves a significant rise in salinity during relatively 
short time frame of a few years, perhaps consistent with a sharp freshwater-saltwater interface as suggested by the Ghyben-Herzberg relationship (Freeze and Cherry 1979). In contrast, the long history of sea level fluctuation along the Atlantic Coastal Plain in eastern USA has resulted in large mixed areas of brackish groundwater (Manheim and Horn 1968; Meisler 1989), which suggests that pumping-induced salinity changes should be more gradual.

Consequently, two decades of pumping in the Outer Banks of Dare County in North Carolina has increased the relative contribution of the underlying fossil and diluted seawater in the upper section of the Yorktown aquifer. Salinity has increased by a factor of $\sim 2.5$, but this has not affected the performance of the RO membrane. A disadvantage of using this type of saline groundwater is the relatively high abundances of trace elements like boron and arsenic that are poorly rejected by the RO membrane as demonstrated in this study. Overall, saline groundwater in coastal aquifers can be an alternative to seawater desalination, but careful examination of the origin of the salinity and its water chemistry is essential for predicting the sustainable long-term utilization of the saline groundwater for RO desalination.

\section{Conclusions}

This study examines the changes in salinity and chemical composition of saline groundwater from the southeastern Atlantic coast in the USA that is used for RO desalination. The salinity of water from the wells in the Yorktown aquifer in the coastal plain of North Carolina that produce feed water for RO desalination in Dare County North Reverse Osmosis Water Plant has increased from about 1,000 to about $2,500 \mathrm{mg} / \mathrm{L}$ since its installation in the late 1980s. Geochemical, oxygen, hydrogen, and boron isotope analysis suggests that the salinity increase is derived from upconing of highersalinity underlying groundwater. Mass balance calculations indicate that the current level of salinity is associated with a contribution of about $20 \%$ of the underlying high-salinity groundwater. The geochemical data rule out contribution of modern seawater intrusion into the Yorktown aquifer. In spite of the salinity increase, the plant demonstrates high rejection performance for monovalent and divalent ions (96-99\% removal). In contrast, the inferred uncharged nature of nearly all of the boron and much of the arsenic results in overall low removal of boron (16-43\%) and arsenic $(54-75 \%)$ by the RO membrane. This requires an additional treatment step in which arsenic is removed by reaction with an iron oxide media. Future salinization may increase the boron content of the raw water and consequently the produced water to as much as $2 \mathrm{mg} / \mathrm{L}$, which would exceed international recommendations for drinking water. In contrast, further salinization should not significantly increase the arsenic content of water produced from the well field. In conclusion, sustainable operation without resorting to higher-cost, higher-salinity seawater desalination is possible due to the large volume of fossil and diluted seawater that occupies the southeastern Atlantic coastal aquifers.

Acknowledgements Dare County Water Department personnel provided access and sampling assistance. Additional field and lab assistance was provided by $\mathrm{H}$. Raanan of the Division of Earth and Ocean Sciences at Duke University, A. Slade of University of Auckland in New Zealand, J. Karr of Duke University Department of Biology, and P. Heine of the Nicholas School of the Environment at Duke University. HS received an undergraduate student research grant awarded by the Duke University Undergraduate Research Support Office. Finally, the associate editor and two anonymous reviewers provided critical and thorough reviews of the manuscript.

\section{References}

AMTA (American Membrane Technology Association) (2011) AMTA membrane water treatment facilities. AMTA, Stuart, FL. http:// www.membranes-amta.org/map.html. Cited 6 Jan 2011.

Andersen MS, Nyvang V, Jakobsen R, Postma D (2005) Geochemical processes and solute transport at the seawater/ freshwater interface of a sandy aquifer. Geochim Cosmochim Acta 69:3979-3994

Barlow PM (2003) Ground water in freshwater-saltwater environments of the Atlantic Coast. US Geol Surve Circ 1262

Cengeloglu Y, Arslan G, Tor A, Kocak I, Dursun N (2008) Removal of boron from water by using reverse osmosis. Sep Purif Technol 64:141-146

Chapelle FH, Knobel LL (1983) Aqueous geochemistry and the exchangeable cation composition of glauconite in the Aquia aquifer, Maryland. Ground Water 21:343-352

Chapelle FH, McMahon PB (1991) Geochemistry of dissolved inorganic carbon in a coastal plain aquifer. 1. Sulfate from confining beds as an oxidant in microbial $\mathrm{CO}_{2}$ production. $\mathrm{J}$ Hydrol 127:85-108

Custodio E (1997) Detection, in seawater intrusion in coastal aquifers: guidelines for study, monitoring, and control. Water reports, FAO, Rome, pp 7-23

Dare County Water Department (2006) North Reverse Osmosis water plant. http://www.co.dare.nc.us/water/NRO/rokdh.htm. Cited 19 April 2009

D'Avino D, Spandre R (1995) Presence of boron in groundwater in the coastal plain of the Cornia River, Italy. J Environ Hydrol 3(1):3-10

dePaul VT, Rice DE, Zapecza OS (2008) Water-level changes in aquifers of the Atlantic Coastal Plain: predevelopment to 2000. US Geol Surv Sci Invest Rep 2007-5247

Dickson AG (1990) Thermodynamics of the dissociation of boric acid in synthetic seawater from 273.15 to $318.15 K$. Deep Sea Res 37:755-766

Dwyer GS, Vengosh A (2008) Alternative filament loading solution for accurate analysis of boron isotopes by negative thermal ionization mass spectrometry. EOS Trans AGU Fall Meet Suppl 89(53), abstract H51C-0824

Environmental Protection Agency (2008) Drinking water health advisory for boron. Document 822-R-08-013, Office of Water, US EPA, Washington, DC

European Community Council Directive (1998) 98/83/EC on the quality of water intended for human consumption. Off $\mathrm{J}$ Eur Comm L330:32-54

Freeze RA, Cherry JA (1979) Groundwater. Prentice-Hall, Englewood Cliffs, NJ

George CM, Smith AH, Kalman DA, Steinmaus CM (2006) Reverse osmosis filter use and high arsenic levels in private well water. Arch Environ Occup Health 61:171-175

Georghiou G, Pashafidis L (2007) Boron in groundwaters of Nicosia (Cyprus) and its treatment by reverse osmosis. Desalination 215:104-110 
Geucke T, Deowan SA, Hoinkis J, Patzold C (2009) Performance of a small-scale RO desalinator for arsenic removal. Desalination 239:198-206

Gorenflo A, Brusilovsky M, Faigon M, Liberman B (2007) High $\mathrm{pH}$ operation in seawater reverse osmosis permeate: first results from the world's largest SWRO plant in Ashkelon. Desalination 203:82-90

Haque S, Ji J, Johannesson KH (2008) Evaluating mobilization and transport of arsenic in sediments and groundwaters of Aquia aquifer, Maryland, USA. J Contam Hydrol 99:68-84

Hyung H, Kim J-H (2006) A mechanistic study on boron rejection by sea water reverse osmosis membranes. J Membr Sci 286:269-278

Jacob C (2007) Seawater desalination: boron removal by ion exchange technology. Desalination 205:47-52

Jones BF, Vengosh A, Rosenthal E, Yechieli Y (1999) Geochemical investigations. In: Seawater intrusion in coastal aquifers: concepts, methods, and practices. Kluwer, Dordrecht, the Netherlands, pp 51-71

Kennedy CD, Genereux DP (2007) ${ }^{14} \mathrm{C}$ Groundwater age and the importance of chemical fluxes across aquifer boundaries in confined Cretaceous aquifers of North Carolina, USA. Radiocarbon 49:1181-1203

Kirk MF, Holm TR, Park J, Jin Q, Sanford RA, Fouke BW, Bethke CM (2004) Bacterial sulfate reduction limits natural arsenic contamination in groundwater. Geology 32:953-956

Kloppmann W, Vengosh A, Guerrot C, Millot R, Pankratov I (2008) Isotope and ion selectivity in reverse osmosis desalination: geochemical tracers for man-made freshwater. Environ Sci Technol 42:4723-4731

Knobel LL, Chapelle FH, Meisler H (1998) Geochemistry of the northern Atlantic Coastal Plain aquifer system. US Geol Surv Prof Pap 1404-L

Lautier, JC (2009) Hydrogeologic framework and ground water conditions in the North Carolina East Central Coastal Plain. Ground Water Management Section Report 30, North Carolina Division of Water Resources, Raleigh, NC

Mane PP, Park P-K, Hyung H, Brown JC, Kim J-H (2009) Modeling boron rejection in pilot- and full-scale reverse osmosis desalination processes. J Membr Sci 338:119-127

Manheim FT, Horn MK (1968) Composition of deeper subsurface waters along the Atlantic continental margin. Southeast Geol 9:215-236

Meisler, H (1989) The occurrence and geochemistry of salty ground water in the northern Atlantic Coastal Plain. US Geol Surv Prof Pap 1404-D

Millero FJ (1995) Thermodynamics of the carbon dioxide system in the oceans. Geochim Cosmochim Acta 59:661-677

Millero FJ, Sohn ML (1991) Chemical oceanography. CRC, Boca Raton, FL

Moore KW, Huck PM, Siverns S (2008) Arsenic removal using oxidative media and nanofiltration. J Am Water Works Assoc 100:74-83

Nadler A, Magaritz M, Mazor E (1980) Chemical reactions of sea water with rocks and freshwater: experimental and field observations on brackish waters in Israel. Geochim Cosmochim Acta 44:879-886

North Carolina Geological Survey (1985) Geologic map of North Carolina, scale 1:500,000, North Carolina Geological Survey, Raleigh, NC

North Carolina Office of State Budget and Management (2010) Annual county populations. North Carolina Office of State Budget and Management, State Demographics Branch. http://www.osbm. state.nc.us/ncosbm/facts_and_figures/socioeconomic_data/ population_estimates/county_projections.shtm. Cited 6 Jan 2011
Oreskovich RW, Watson IC (2003) Dealing with arsenic (III) in brackish water RO permeate. International Desalination Association proceedings BAH03. http:/www.idadesal.org/publica tions/Summary.asp? UniqueID $=3028$. May 2003

Ozturk N, Kavak D, Kose TE (2008) Boron removal from aqueous solution by reverse osmosis. Desalination 223:1-9

Parks JL, Edwards M (2005) Boron in the environment. Crit Rev Environ Sci Technol 35:81-114

Pawlak Z, Zak S, Zablocki L (2006) Removal of hazardous metals from groundwater by reverse osmosis. Pol J Environ Stud 15:579-583

Prats D, Chillon-Arias MF, Rodriguez-Pastor M (2000) Analysis of the influence of $\mathrm{pH}$ and pressure on the elimination of boron in reverse osmosis. Desalination 128:269-273

R Development Core Team (2009) R: a language and environment for statistical computing. R Foundation for Statistical Computing, Vienna

Ranjan P, Kazama S, Sawamoto M (2006) Effects of climate change on coastal fresh groundwater resources. Glob Environ Change 16:388-399

Sagiv A, Samiat R (2004) Analysis of parameters affecting boron permeation through reverse osmosis membranes. J Membr Sci 243:79-87

Salgot M, Tapias JC (2004) Non-conventional water resources in coastal areas: a review on the use of reclaimed water. Geol Acta 2:121-133

Scanlon BR, Nicot JP, Reedy RC, Kurtzman D, Mukherjee A, Nordstrom DK (2009) Elevated naturally occurring arsenic in a semiarid oxidizing system, Southern High Plains aquifer, Texas, USA. Appl Geochem 24:2061-2071

Schmidt GA, Bigg GR, Rohling EJ (1999) Global seawater oxygen18 database, version 1.19a. http://data.giss.nasa.gov/o18data. Cited 16 Nov 2010

Sivan O, Yechieli Y, Herut B, Lazar B (2005) Geochemical evolution and timescale of seawater intrusion into the coastal aquifer of Israel. Geochim Cosmochim Acta 69:579-592

Smedley PL, Kinniburgh DG (2002) A review of the source, behaviour and distribution of arsenic in natural waters. Appl Geochem 17:517-568

Spivack AJ, Palmer MR, Edmond JM (1987) The sedimentary cycle of the boron isotopes. Geochim Cosmochim Acta 51:19391949

Taylor HE (2001) Inductively coupled plasma-mass spectrometry: practices and techniques. Academic, San Diego, CA

Vengosh A (2003) Salinization and saline environments. In: Sherwood Lollar B (ed) Treatise on geochemistry, vol 9. Elsevier, Amsterdam, pp 333-365

Vengosh A, Spivack AJ (1999) Boron isotopes in groundwater. In: Cook PG, Herczeg AL (eds) Environmental tracers in subsurface hydrology. Kluwer, Dordrecht, the Netherlands, pp 479-485

Vengosh A, Gill J, Davisson ML, Hudson GB (2002) A multiisotope $(\mathrm{B}, \mathrm{Sr}, \mathrm{O}, \mathrm{H}$, and $\mathrm{C})$ and age dating $\left({ }^{3} \mathrm{H}^{3} \mathrm{He}\right.$ and $\left.{ }^{14} \mathrm{C}\right)$ study of groundwater from Salinas Valley, California: hydrochemistry, dynamics, and contamination processes. Water Resour Res 38: doi: 10.1029/2001WR000517

Walker M, Seiler RL, Meinert M (2008) Effectiveness of household reverse-osmosis systems in a western US region with high arsenic in groundwater. Sci Total Environ 389:245-252

Weinthal E, Parag Y, Vengosh A, Muti A, Kloppmann W (2005) The EU Drinking Water Directive: the boron standard and scientific uncertainty. Eur Environ 15:1-12

Winner MD, Coble RW (1996) Hydrogeologic framework of the North Carolina coastal plain. US Geol Surv Prof Pap 1404-I

World Health Organization (2008) Guidelines for drinking-water quality, incorporating 1st and 2nd addenda, vol 1: Recommendations, 3rd edn. WHO, Geneva 